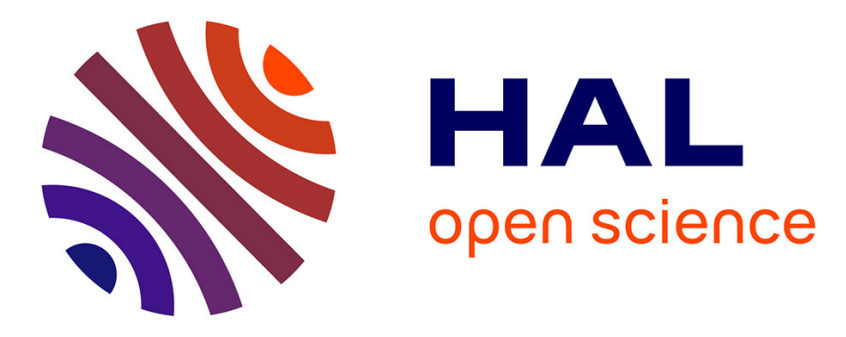

\title{
Spectroscopic properties of LaF3:Tm3+ nanoparticle-doped silica optical fibers
}

\author{
Manuel Vermillac, Jean-François Lupi, Michèle Ude, Stanislaw Trzesien, \\ Bernard Dussardier, Wilfried Blanc, Olivier Tottereau, Philippe Vennegues, \\ Courtney Kucera, J. Furtick, et al.
}

\section{To cite this version:}

Manuel Vermillac, Jean-François Lupi, Michèle Ude, Stanislaw Trzesien, Bernard Dussardier, et al.. Spectroscopic properties of LaF3:Tm3+ nanoparticle-doped silica optical fibers. Specialty Optical Fibers \& Applications, Jul 2014, Barcelona, Spain. hal-01060054

\section{HAL Id: hal-01060054 https://hal.science/hal-01060054}

Submitted on 2 Sep 2014

HAL is a multi-disciplinary open access archive for the deposit and dissemination of scientific research documents, whether they are published or not. The documents may come from teaching and research institutions in France or abroad, or from public or private research centers.
L'archive ouverte pluridisciplinaire HAL, est destinée au dépôt et à la diffusion de documents scientifiques de niveau recherche, publiés ou non, émanant des établissements d'enseignement et de recherche français ou étrangers, des laboratoires publics ou privés. 


\title{
Spectroscopic properties of $\mathrm{LaF}_{3}: \mathrm{Tm}^{3+}$ nanoparticle-doped silica optical fibers
}

\author{
M. Vermillac ${ }^{1}$, J.F. Lupi ${ }^{1}$, M. Ude ${ }^{1}$, S. Trzesien ${ }^{1}$, B. Dussardier ${ }^{1}$, W. Blanc ${ }^{1, *}$, O. Tottereau ${ }^{2}$, P. Vennegues ${ }^{2}$, C. \\ Kucera $^{3}$, J. Furtick ${ }^{3}$, J. Ballato ${ }^{3}$ \\ 1 Université Nice Sophia Antipolis, CNRS, LPMC UMR 7336, Parc Valrose, 06100 Nice, France \\ 2 CNRS-CRHEA, rue Bernard Grégory, 06560 Valbonne, France \\ 3 Department of Materials Science and Engineering, and the Center for Optical Materials Science and Engineering Technologies (COMSET), \\ Clemson University, Clemson, SC, USA \\ Authore-mail address: wilfried.blanc@unice.fr
}

\begin{abstract}
Silica-based fibers doped with $\mathrm{LaF}_{3}: \mathrm{Tm}^{3+}$ nanoparticles, prepared by MCVD and solution doping exhibited a fluorescence lifetime of $55 \mu$ s at 810 and $1470 \mathrm{~nm}$, with background losses below $0.1 \mathrm{~dB} / \mathrm{m}$ at $1300 \mathrm{~nm}$.

OCIS codes: (060.2270) Fiber characterization; (060.2290) Fiber materials; (160.4236)

Nanomaterials; (160.5690) Rare-earth-doped materials; (160.6030) Silica.
\end{abstract}

\section{Introduction}

Lasers and amplifiers based on rare-earth (RE)-doped silica optical fibers are of great interest for many applications. However, silica glass as a host for RE imposes some limitations to the development of devices having improved spectroscopic performances: gain curve engineering, photodarkening, spectral coverage, etc. For the latter application, the case of thulium ion $\left(\mathrm{Tm}^{3+}\right)$ is typical: the high-phonon energy of silica prevents the implementation of interesting optical transitions of $\mathrm{Tm}^{3+}$ ions at 0.8 and $1.47 \mu \mathrm{m}$, because fast non-radiative decay (NRD) from the ${ }^{3} \mathrm{H}_{4}$ metastable level to the ${ }^{3} \mathrm{H}_{5}$ level prevents population inversion. Hence, the resulting ${ }^{3} \mathrm{H}_{4}$-lifetime in silica and $\mathrm{LaF}_{3}$ are measured at $14 \mu \mathrm{s}$ and $2 \mathrm{~ms}$ [1], respectively. To mitigate NRD, a route of interest consists of embedding the RE ions within nanoparticles of composition and structure different from those of silica. That would provide a beneficial local environment to RE ions in terms of spectroscopic properties [2], like diminishing the effective host phonon-energy. In this work we study the properties of silica-based, MCVD-prepared fibers using $\mathrm{LaF}_{3}: \mathrm{Tm}^{3+}(1 \mathrm{~mol}$ $\%$ nanoparticles as the RE carrier during the fabrication process. The $10-20 \mathrm{~nm}$ diameter nanoparticles were produced by precipitation methods [3], suspended in ethanol and were incorporated by solution doping into the core of a preform made using MCVD [4]. Porous layer densification, preform collapsing and fiber drawing were performed conventionally. Importantly, no post-process heat treatment was applied on the fiber.

\section{Results}

Through SEM analyses on preform and fiber, nanodomains of average size 10-20 nm (SEM resolution limited) were observed across the core. The fiber background losses was less than $0.1 \mathrm{~dB} / \mathrm{m}$ at $1300 \mathrm{~nm}$. The first e-folding time of the 810-nm emission band $\left({ }^{3} \mathrm{H}_{4}\right.$ level) was $55 \mu$ under 785 -nm excitation. Although it is much less than that in bulk $\mathrm{LaF}_{3}$, it is 4 to 5 times larger than that reported in pure silica, close to that reported in alumino-silicate fibers with $9 \mathrm{~mol} \%$ of $\mathrm{Al}_{2} \mathrm{O}_{3}$ [5]. Here only $1 \%$ of $\mathrm{LaF}_{3}$ addition, on average, to the fiber core suffice to obtain the same spectroscopic alteration. Further spectroscopic and material characterizations are under progress to interprete theses results and assess the potential of this type of fiber for future applications.

\section{References}

[1] S. Huang et al., "Upconversion in $\mathrm{LaF}_{3}: T m^{3+’,}$ Phys. Rev. B 24, 59-63 (1981)

[2] M. Clara Gonçalves et al., "Rare-earth-doped transparent glass ceramics", C.R. Chimie 5, 845-854 (2002)

[3] C. Kucera et al., "Designer Emission Spectra through Tailored Energy Transfer in Nanoparticle Doped Silica Preforms," Opt. Letters 34, $2339-2341(2009)$

[4] O. Sysala et al., "Preparation of preforms and optical fibres containing aluminium by the solution-doping method", Ceramics 4, 363-366 (1991)

[5] B. Faure et al., "Improvement of the $\mathrm{Tm}^{3+} .{ }^{3} \mathrm{H}_{4}$ level lifetime in silica optical fibers by lowering the local phonon energy", J. Non-Cryst. Solids 353, 2767-2773 (2007) 